CENDEKIA, Vol. 13 No. 2 Oktober 2019

p-ISSN: 1978-2098; e-ISSN: 2407-8557

Https://soloclcs.org; Email: cendekiaoslo@gmail.com

Center of Language and Cultural Studies, Surakarta, Indonesia

Irwansyah. (2019). Analisis Kemampuan Memproduksi Teks Anekdot dengan Pendekatan Saintifik Siswa Kelas X MAN 1 Bima: Kajian Teks dalam Pembelajaran Bahasa Indonesia Prof. Mahsun, M.Pd. Cendekia (2019), 13(2): 87-98. DOI: 10.30957/cendekia.v13i2.598..

\title{
Analisis Kemampuan Memproduksi Teks Anekdot dengan Pendekatan Saintifik Siswa Kelas X MAN 1 Bima: Kajian Teks dalam Pembelajaran Bahasa Indonesia Prof. Mahsun, M.Pd
}

\author{
Irwansyah \\ Jurusan Bahasa Indonesia dan Sastra Indonsia \\ Sekolah Tinggi Ilmu Ekonomi Yapis Dompu \\ Jalan Syech Muhammad Lingkar Utara Bali 1 Dompu NTB \\ Email: danuaja36@gmail.com
}

\begin{abstract}
This study aims to describe the ability of students at $\mathrm{x}$ grade students of MAN 1 Bima in writing anecdotal text with scientific approach. Therefore to know this problem used the theory of qualitative data analysis and quantitative analysis by using tabulation width of student learning achievement in book of Prof. Mahsun, MS, and other theories. The research method used in this research is qualitative research method with the character of analytic description. Interpretation of data is done through literature method and field observation with student assignment technique writing anecdote text using scientific approach. Based on the results of data analysis, it can be concluded that the students' ability to analyze at $\mathrm{x}$ grade students of MAN 1 Bima in writing anecdotal text with scientific approach is at less skilled value, This is evidenced from the results from students' score that is only under minimum score. This is also evidenced from the results of qualitative data analysis and the score of students is only in the range under the minimum score. it is also evidenced from the results of qualitative data analysis and quantitative data analysis used tabulation data sheet that shows the number of the ability to write anecdote text of all student got score 30 that is in the less skilled value category.
\end{abstract}

Keywords: ability to write, scientific approach, anecdotal text ..

\section{PENDAHULUAN}

Kemampuan menulis menjadi problem yang sangat rumit yang dijalani oleh setiap orang yang menggeluti dunia pendidikan, hal ini tentu diakibatkan oleh keterbatasan seseorang memamahami struktur penulisan yang baik dan benar. Lebih lanjut, kurikulum 2013 pada mata pelajaran bahasa Indonesia telah menerapkan pembelajaran berbasis teks pada proses pengajaran pelajaran bahasa indonesia, terntu hal demikian menambah beban baru bagi setiap guru bahasa indonesia maupun siswa.

Adanya Perubahan dalam pembelajaran bahasa Indonesia tersebut seyogya nya diiringi dengan kompetensi guru dalam mengimplementasikan pembelajaran bahasa 
CENDEKIA, Vol. 13 No. 2 Oktober 2019

p-ISSN: 1978-2098; e-ISSN: 2407-8557

Https://soloclcs.org; Email: cendekiaoslo@gmail.com

Center of Language and Cultural Studies, Surakarta, Indonesia

Irwansyah. (2019). Analisis Kemampuan Memproduksi Teks Anekdot dengan Pendekatan Saintifik Siswa Kelas X MAN 1 Bima: Kajian Teks dalam Pembelajaran Bahasa Indonesia Prof. Mahsun, M.Pd. Cendekia (2019), 13(2): 87-98. DOI: 10.30957/cendekia.v13i2.598..

dengan pradigma baru yaitu pembelajaran berbasis "teks". Agar ke depan siswa juga mampu memiliki kemampuan dalam menulis.

Berbicara perihal menulis teks, siswa kelas XMAN 1 Bima juga mengalami hambatan yang bersifat pra penulisan. Hal ini disebabkan oleh rendahnya budaya membaca siswa yang mempengaruhi tingkat penguasaan kosakata dan pemamahaman mengenai pirant-piranti kebahasaan teks. Kondisi ini mengakibatkan siswa mengalami kesulitan menungkan ide, gagasan, data atau informasi kedalam bentuk rangkaian kalimat-kalimat, sehingga mendorong mereka melakukan plagiasi ketika mendapakan tugas menulis sebuah teks dari guru.

Lebih lanjut, hal lain adalah kurangnya minat siswa dalam mengasah keterampilan menulis, disebabkan oleh kejenuhan siswa dalam mengkaji atau menganalisis setiap teks yang tersaji dalam kurikum 2013. Disamping itu kurangnya motivasi siswa terhadap materi pembelajaran bahasa indonesia dipengaruhi oleh adanya pemetaan siswa sesuai dengan bidangnya dan minat mereka. Sehingga mengakibatkan siswa hanya mau berkosentrasi serius pada bidang yang mereka sukai, kemudian mengakibatkan materi-materi umum seperti bahasa indoensia menjadi kurang diminati. Dalam hal ini siswa menyampingkan pemebelajaran bahasa indonesia.

Kemudian patut ditambahkan permasalahn yanag muncul disekolah adalah dilatarbelakangi oleh lingkungan yang secara fasilitas tidak memberikan dukungan dalam memenuhi kebutuhan siswa dalam mendukung kediatan membaca. Karena memang secara geografis bima merupakan daerah yang cukup terbelakang secara fasilitas, pendidikan, maupun ekonomi. Hal ini, secara tidak langsung masalah tersebut mepengaruhi juga pada motivasi membaca dan menulis siswa di bima itu sendiri.

Dari masalah yang muncul diatas teks anekdot diharapkan dapat meberikan dampak yang baik pada motivasi siswa dalam hal membaca dan lebih-lebih pada hal menulis. Teks anekdot tidak hanya diharapkan meberikan pengajaran siswa dalam menulis teks akan tetapi, teks anekdot diharapakan juga dapat meberikan suasana belajar yang menyenangkan dalam susana kelas yang humoris.

Menghadapi permaslahan siswa yang acapkali malas ketika menerima pembelajaran didalam kelas, teks anekdot ini juga diharapkan mampu meberikan semagat humoris dan semanagat menulis teks pada siswa tersebut. kemudian teks anekdot juga secara sadar akan mampu meberikan tingkat keseriusan siswa dalam menerima materi pembelajaran. Karena teks anekdot itu merupakan salah satu jenis teks genre sastra yang mampu menimbulkan semangat humoris kepada siswa kususnya untuk siswa MAN 1Bima.

Menanggapi berbagai macam masalah yang muncul diatas penelitian yang secara spesisfik mengkaji bagaimana menangani masalah dalam pembelajaran bahasa indonesia yang berbasis teks. Penelitian ini dapat dikatakan layak untuk dilakukann, guna mendeskripsikan kemampuan siswa kelas X di sekolah MAN 1 BIMA dalam menulis teks anekdot dengan metode santifik.

Kemudian berbicara tentang metode menulis teks, yaitu pendekatan saintifik merupakan pendekatan yang sangant relevan dengan kurikulum 2013 yang menerapakan pembelajaran berbasis teks pada pelajaran bahasa indonesia. pendekatan 
CENDEKIA, Vol. 13 No. 2 Oktober 2019

p-ISSN: 1978-2098; e-ISSN: 2407-8557

Https://soloclcs.org; Email: cendekiaoslo@gmail.com

Center of Language and Cultural Studies, Surakarta, Indonesia

Irwansyah. (2019). Analisis Kemampuan Memproduksi Teks Anekdot dengan Pendekatan Saintifik Siswa Kelas X MAN 1 Bima: Kajian Teks dalam Pembelajaran Bahasa Indonesia Prof. Mahsun, M.Pd. Cendekia (2019), 13(2): 87-98. DOI: 10.30957/cendekia.v13i2.598..

saintifik juga merupakan salah satu metode yang di anggap mudah dipahami oleh siswa karena tehnik atau proses yang digunakan dalam metode saintifik hanya bersisfat seperti permainan kata yang dirubah menjadi kalimat, kemudian kalimat menjadi paragraf dan pada ahirnya menjadi sebuah cerita yang utuh.

Dengan adanya penelitian ini maka diharapkan siswa tidak hanya mampu dalam memahami atau mengenal jenis teks saja akan tetapi yang paling penting adalah siswa mampu juga dalam menulis teks sendiri terutama dalam menulis teks anekdot. Dengan adanya penelitian ini juga guru dapat dengan mudah memberikan pelajaran berbasis teks dengan baik terhadap siswa dan juga siswa mendapatkan kemudahan dalam menulis teks.

Mahsun (2014:15) menjelaskan bahwa secara umum, teks dapat diklasifikasikan atas teks tunggal/ genre mikro dan teks majemuk/genre makro. Istila tunggal dan majemuk yang sematkan pada konsep teks tunggal dan teks majemuk beranalogi pada konsep tunggal dan majemuk dalam kalimat tunggal dan kalimat majemuk. Kalimat tunggal adalah memiliki satu pola dasar kalimat inti (PDKI), minimal memiliki subjek dan predikat untuk kalimat tunggal yang berwatak intransitif atau memiliki subjek,predika,objek untuk kalimat-kalimat yang berwatak transitif. Adapun kalimat majemuk adalah kaliat yang memiliki lebih dari satu pola dasar kalimat inti. Dalam hubunganya dengan bahsa sebagai sarana komunikasi, maka bayhasa hanya muncul dalam proses sosial. Beberapa proses sosial utama yang dilakukan melalui tindakan berbahasa dapat berupa penggambaran,penjelasan, penrintah,penyajian,alasanalasan/argumentasi dan penceritaan. Melalui proses inilah lahir beberapa jenis teks yang menyangkut genre cerita. Misalnya dongeng,mite,fable,cerita personal,cerita sejarah dan sebagainya (Mahsun, 2014:17).

Berbicara tentang teks tidak dapat dilepaskan dari pembicaraan tentang genre dan register, karena kedua hal diatas memiliki relasi herarki dengan teks itu sendiri. Genre merujuk pada nilai atau norma-norma kultural yang direalisasikan dalam suatu proses sosial. Dengan demikian, genre dapat didefinisiskan sebagai jenis teks yamg berfungsi menjadi rujukan agar suatu teks dapat dibuat lebih efektif, baik dari segi kmetepatan tujuan (tujabn sosial), maupun ketepatan pemilihan dan penyusunan elemen teks, dan ketepatan dalam penggunaan unsur tata bahasanya (badingkan dengan pradiyono, 2007:2).

Berdasarkan sudut pandang penceritaan, maka genre atau ragam teks tersebut dapat dipilih kedalam dua kelompok besar yaitu teks-teks yang termasuk dalam genre sastra dan genre non sastra, sementara itu, teks-teks dalam kelompok genre sastra dikategorikan ke dalam genre cerita, sedangakan teks-teks genre non sastra dikelompokan ke dalam genre faktual dan genre tanggapan. Baik genre cerita maupun genre faktualdan genre tanggapan maising dikelompokan kedalam dua kelompok subgenre yaitu:

1. Subgenre naratif dsn non naratif untuk kategori genri cerita;

2. Subgenre laporan dan prosedural untuk kategori genre faktual ; dan

3. Subgenre transaksional dan ekspositori untuk kategori genre tanggapan. 
CENDEKIA, Vol. 13 No. 2 Oktober 2019

p-ISSN: 1978-2098; e-ISSN: 2407-8557

Https://soloclcs.org; Email: cendekiaoslo@gmail.com

Center of Language and Cultural Studies, Surakarta, Indonesia

Irwansyah. (2019). Analisis Kemampuan Memproduksi Teks Anekdot dengan Pendekatan Saintifik Siswa Kelas X MAN 1 Bima: Kajian Teks dalam Pembelajaran Bahasa Indonesia Prof. Mahsun, M.Pd. Cendekia (2019), 13(2): 87-98. DOI: 10.30957/cendekia.v13i2.598..

Priyanti (2014:65) menyatakan bahwa teks adalah ujaran (lisan) atau tulis bermakna yang berfungsi untuk mengekspresikam gagasan, lebih lanjut priyanti (2014:66) bahwa suatu tindakan komunikasi yang dilakukan untuk mencapai suatu tujan tertentu diwujudkan dalam bentuk kongkrit berupa teks.

\section{Rumusan Masalah}

Dengan melihat latarbelakang di atas maka dapat dirumuskan sebuah masalah sebagai berikut bagaimanakah kemampuan siswa X MAN 1 Bima dalam menulis teks anekdot dengan menggunakan pendekatan saintifik?

\section{LANDASAN TEORI}

\subsection{Teks anekdot}

Wiratno 2014 (dalam Mahsun) adalah sebagai salah satu jenis teks yang termasuk dalam genre cerita, teks anekdot memiliki tujan sosial yang sama dengan teks cerita ulang hanya saja, peristiwa yang ditampilkan membuat partisipan yang mengalaminya merasa jengkel atau konyol.

Anekdot merupakan salah satu jenis dari humor, akan tetapi seringkali anekdot dianggap sebagai humor itu sendiri. Oleh karena itu penguraian mengenai humor akan lebih menjelaskan pengertian dari anekdot yang dimaksud. Humor menurut Encyclopaedia Britannica merupakan suatu stimulus yang mengundang rasa geli atau terawa. Stimulus atau rangsangan tersebut dapat berupa ide, masalah yang benar lucu, peristiwa yang ada di hadapan kita, perilaku non verbal, atau berupa bentuk kebahasaan yang sengaja dikreasikan.

Pembicaraan mengenai anekdot dan lelucon sudah lama dilakukan para ahli. Ada ahli yang menyamakan antara anekdot dan lelucon, seperti Antti Aerne dan Stitth Thompson, ada pula yang membedakannya seperti Jan Harold Brunvand. James Danandjaja (1994:117-118) menggabungkan sebagian dari kedua pendapat tersebut. Perbedaan antara anekdot dan lelucon terletak pada objeknya. Anekdot adalah kisah fiktif lucu seorang tokoh ataubeberapa tokoh yang benar-benar ada; sedangkan lelucon adalah kisah fiktif lucu anggota suatu kolektif, seperti suku bangsa, golongan, bangsa, dan ras. Jadi jika anekdot dapat dianggap sebagai riwayat hidup fiktif pribadi tertentu, lelucon dapat dianggap sebagai sifat atau tabiat fiktif lucu anggota suatu kolektif tertentu. Maka anekdot dan lelucon sebenarnya tidak dapat disejajarkan, apabila menilik dari isi ceritanya.

Pada buku siswa (wajib) yang berjudul Bahasa Indonesia Ekspresi Diri dan Akademik (2014:99), anekdot ialah cerita singkat yang menarik karena lucu dan mengesankan, biasanya mengenai orang penting atau terkenal dan berdasarkan kejadian yang sebenarnya. Selain itu, anekdot merupakan cerita rekaan yang tidak harus didasarkan pada kenyataan yang terjadi di masyarakat, partisipan atau pelaku di dalamnya pun tidak harus orang penting. Teks anekdot juga berisi peristiwa yang membuat perasaan jengkel atau konyol, dimana perasaan tersebut merupakan krisis yang ditanggapi dengan reaksi dari pertentangan antara nyaman dan tidak nyaman, puas dan frustasi, serta tercapai dan gagal. Anekdot merupakan salah satu genre sastra yang 
biasanya untuk merefleksikan diri maupun isu-isu yang tengah hangat dan menjadi fenomena di lingkungan kehidupan bermasyarakat.

Teks anekdot merupakan teks yang memunyai struktur, struktur teks tersebut digunakan untuk mempermudah dalam membuat teks. Struktur merupakan unsur yang secara tersusun terdapat dalam teks. Berikut struktur yang terdapat dalam teks anekdot.

\section{Abstraksi}

Merupakan bagian awal yang berfungsi memberi gambaran tentang isi teks. Biasanya bagian ini menunjukan hal unik yang ada dalam teks.

\section{Orientasi}

Bagian yang menunjukan awal kejadian cerita atau latar belakang bagaimana peristiwa terjadi.

\section{Krisis}

Bagian di mana terjadi hal atau masalah yang unik atau tidak biasa terjadi pada penulis atau orang yang diceritakan.

\section{Reaksi}

Bagian bagaimana penulis atau orang yang ditulis menyelesaikan masalah yang timbul di bagian krisis tadi.

Koda

Bagian akhir cerita unik tersebut. Bisa juga dengan memberi kesimpulan tentang kejadian yang dialami penulis atau orang yang ditulis

Anekdot memiliki elemen teks yang disusun secara retorik yakni judul, abstrak, orientasi, krisis, reaksi, koda. Berikut penjelasan mengenai unsur-unsur struktur retorik anekdot menurut Pardiyono (2007:292).

1) Judul berbentuk frase yang berisi satu topik kejadian di masa lalu untuk dibagikan dengan para pembaca.

2) Abstrak sangat umum berupa suatu pernyataan retorik atau pernyataan yang berupa eklamasi. Bagian abstrak adalah bagian yang bisa menentukan apakah para pembaca tertarik secara emosional untuk melakukan sharing.

3) Orientasi berisi pengantar cerita, atau latar cerita.

4) Krisis berisi pemaparan kejadian puncak atau insiden yang merupakan inti dari kekonyolan cerita atau kekonyolan kejadian.

5) Reaksi berisi reaksi atau tindakan solusi yang diambil atau dilakukan oleh penulis untuk mengatasi atau menyelamatkan diri dari insiden tersebut.

6) Koda adalah penutup cerita yang merupakan akhir atas insiden tersebut. 
CENDEKIA, Vol. 13 No. 2 Oktober 2019

p-ISSN: 1978-2098; e-ISSN: 2407-8557

Https://soloclcs.org; Email: cendekiaoslo@gmail.com

Center of Language and Cultural Studies, Surakarta, Indonesia

Irwansyah. (2019). Analisis Kemampuan Memproduksi Teks Anekdot dengan Pendekatan Saintifik Siswa Kelas X MAN 1 Bima: Kajian Teks dalam Pembelajaran Bahasa Indonesia Prof. Mahsun, M.Pd. Cendekia (2019), 13(2): 87-98. DOI: 10.30957/cendekia.v13i2.598..

\subsection{Pendekatan Saintifik}

Mahsun (2014:123) mengatakan pendekatan saintifik/ilmiah dalam proses pembelajaran dapat dimaknai sebagai pendekatan yang bersifat empirik yang dilakukan dengan cara sistematis, terkontrol dan kritis yang dimulai dari pengamatan, mempertanyakan, pengumpulan data/informasi,penganalisisan, penghubung sampai pada tahap penyajian.

Lebih lanjut Kurniawan (2015:21) menambahkan bahwa pendekatan saintifik diyakini sebagai titian emas perkembangan dan pengembangan sikap, keterampilan, dan pengetahuan siswa. Perihal pendekatan ilmiah dalam menghasilkan teks diperlukan data. Informsasi, atau fakta yang sangat terkait dengan jenis teks yang akan dihasilakan. Beberapa jenis teks tertentu memiliki wujud data yang berbeda. Perbedaan wujud data disebabkan oleh adanya perbedaan fungsi atau tujuan sosial dari setiap teks dan berimplikasi pada adanya perbedaan dalam pengumpulan data, analisis data, serta penyajian hasil analis.

Mahsun (2014) menjelaskan terdapat dua jenis kebenaran, yaitu kebenaran yang bersumber dari tuhan yang maha esa pencipta dan kebenaran yang bersumber dari hasil ilmu pengetahuan. Kebenaran pertama disebut juga kebenarana illahia, sedangkan kebenaran yang kedua disebut juga kebenaran ilmiah. Kebenaran ilahia bersifat absolut, berlaku pada semua kondisi, tidak terikat pada waktu dan tempat. Kebenaran jenis yang pertama ini diperoleh dari wahyu ilahiya yang dapat ditemukan dalam kita-kitab agama samawi. Oleh karena itu, kebenaran yang tipe pertama diperoleh dari pendekatan keagamaan (religius). Adapun kebenaran yang jenis kedualebih bersifat kebenaran metodelogis. Kebenaran tipe ini diperoelh melalui penelitian terhadap gejala alam dengan metode ilmiah, yaitu suatu kajian terhadap gejala alam yang dilakukan secara sistematis, terkontrol, empiris, dan kritis terhadap proposisi-propossi hipotesi tenntang hubungan yang diperkirakan antar gejala alam (periksa kerlinger, 1993). Dengan kata lain, kebenaran ilmiah merupakan kebenaran yang diperoleh melalui pendekatan saintifik. Oleh karena itu, kebenaran ilmiah bersifat kondsional, terikat pada ruang dalam waktu, serta dapat berubah sesuai dengan perubahan metodelogi.

\section{Ciri-ciri pendekatan saintifik}

Berdasarkan batasan di atas, dapat ditentukan ciri-ciri pendekatan ilmiah sebagai berikut.
a. Sitematis
b. Terkontrol
c. Empirik
d. Kritis

\section{METODE}

Penelitian ini bermuara pada upaya pemecahan masalah dan terbentuknya pemahaman yang komperhensif menegenai gejala atau fenomena yang diamati. Penelitian sebaiknya didukung oleh referensi atau dta-data yang relevan dna dapat merepresentasekan perilaku atau tindakan penerapan metode saintifik terhadap 
keterampilan menulis teks anekdot dan kemampuan siswa produksi teks anekdot melalui metode siantifik, yang menjadi objek dan konteks penelitian. Wujud data dalam penelitiaan ini adalah lembar penyimakan dan pengamatan perilaku guru ketika menerapkan metode saintifik dalam menjelaskan prosedur menulis teks anekdot dan tehnik yang digunakan disesuikan dengan karakteristik dan wujud data penelitian. Dalam penelitian ini akan ditempuh tiga tahap upaya strategis yang berurutan, yaitu tahap penyediaan data, tahap penganalisisan data, dan tahap penyajian hasil analisis data (lihat sudaryanto, 2015 dan Mahsun 2012).

\subsection{Pendekatan Penelitian}

Metode penelitian kualititatif adalah metode yang berlandaskan pada filsafat postpositivisme, digunakan untuk meneliti pada kondisi obyek yang alamiah, (sebagai lawannya adalah eksperimen) dimana penelitian adalah sebagai instrumen kunci, pengambilan sampel sumber data dilakukan secara purposive dan snowbaal, tehnik pengumpulan dengan trianggulasi (gabungan), analisis data bersifat induktif/kualitatif, dan hasil penelitian kualitatif lebih menekankan makna dari pada generalisasi (Sugiyono, 2016:15).

Menurut Bogdan dan Taylor yang dikutip oleh maleong, menyatakan bahawa metode penelitian yang menghasilkan data dekkriptif berupa kata-kata tertulis atau lisan dari orang-orang dan perilaku yang dimamati (Maleong, 1991:3). Melihat karakteristik penelitian dan wujud data penelitian kemudaian dilihat dari judul penelitian. Maka penelitian ini dapat dikatakan sebagai jenis penelitian kualitatif . pada penelitian ini, wujud data dapat berupa penugasan siswa. Penugasan guru, wawancara guru dan siswa, materi pembelajaran, dokumen silabus, RPP dll.

\subsection{Sumber Data}

a. Data Primer

1. Informasi wawancara Siswa kelas X MAN 1 Bima dan hanya diambil dari kelas X IPA I dan kelas IPA II.

2. Informasi wawancara Guru yang mengajar mata pelajaran bahasa indonesia

3. Informasi sekolah dan diperoleh dari orang yang terlibat langsung di sekolah tersebut

\section{b. Data Sekunder}

Data sekunder dalam penelitian ini adalah data yang diperoleh bukan secara langsung dari sumbernya. Penelitian ini sumber data sekunder yang dipakai adalah sumber tertulis seperti sumber buku bahasa Indonesia pengangan guru dan siswa, RPP Bahasa indonesia, silabus bahasa indonesia. Lembar tugas siswa dan teks anekdot menggunakan pendekatan saintifik.

\subsection{Teknik Pengumpulan Data}

Menurut Sutopo (2006:9), metode pengumpulan data dalam penelitian kualitatif secara umum dikelompokkan ke dalam dua jenis cara, yaitu teknik yang bersifat interaktif dan non-interaktif. Metode interaktif meliputi interview dan observasi 
CENDEKIA, Vol. 13 No. 2 Oktober 2019

p-ISSN: 1978-2098; e-ISSN: 2407-8557

Https://soloclcs.org; Email: cendekiaoslo@gmail.com

Center of Language and Cultural Studies, Surakarta, Indonesia

Irwansyah. (2019). Analisis Kemampuan Memproduksi Teks Anekdot dengan Pendekatan Saintifik Siswa Kelas X MAN 1 Bima: Kajian Teks dalam Pembelajaran Bahasa Indonesia Prof. Mahsun, M.Pd. Cendekia (2019), 13(2): 87-98. DOI: 10.30957/cendekia.v13i2.598..

berperanserta, sedangkan metode noninteraktif meliputi observasi takberperanserta, tehnik kuesioner, mencatat dokumen, dan partisipasi tidak berperan.

Sedangkan Sugiyono (2008:63) ada empat macam tehnik pengumpulan data, yaitu observasi, wawancara, dokumentasi dan gabungan/triangulasi.

\subsection{Teknik Analisis Data}

Sesuai dengan hakikat analisis data yang satu dengan yang lain yang berhasil disediakan dengan tujuan pengelompokan, penyamaan data yang sama dan pembedaan data yang memang berbeda, serta penyisihan pengelompok lain data serupa seperti tak sama, maka metode analisis data yang digunakan dalam aktifitas penelitian, termasuk penelitian pembelajaran bahasa adalah metode padan (Mahsun, 2017:176).

Terdapat dua jenis metode padan, yaitu metode padan intralingua dan metode padan ekstralingua. Istila intralingua mengacu pada makna unsur-unsur yang berada dalam bahasa (bersifat lingua), mislanya unsur-unsur yang berupa bangunan kebahasaan teks. Jadi, dalam konteks metodelogis dengan contoh judul yang menjadi ilustrasi, konsep metode padan intralingua dimaksudkan sebagai cara analisis yang membandingkan subtansi teks, seperti membandingkan unsur kohesivitas dan koherensia teks anekdot yang diperoleh dari buku bahasa indonesia kurikulum 2013 dengan unsur kohesivitas dan koherensia teks standar (Mahsun, 2017:379).

Lebih jelas bahwa metode padan intralingual memiliki tehnik-teknik, yaitu tehnik hubung banding menyamakan (HBS), hubung banding membedakan (HBB), dan tehnik hubung banding menyamakan hal pokok (HBSP). Tehnik HBSP yaitu tehnik yang bertujuan untuk mencari kesamaan hal pokok dari perbedaan dan penyamaan yang dilakukan dengan tehnik HBS dan HBB, karena tujuan ahir dari banding menyamakan atau banding membedakan tidak lain adalah menemukan kesamaan pokok diantara data yang diperbandingkan itu.

Hal yang sama terjadi pada metode padan ekstralinguam yaitu metode ini memiliki tehnik-tehnik yang sama dengan tehnik yang terdapat dalam metode padan intralingua.hanya saja dihubung bandingkan untuk menyamakan, membedakan, atau menyamakan hal pokok itu adalah masalah kebahasaan dengan hal-hal yang diluar bahasa, seperti penutur bahasa (responden) yang dipilih berdasarkan kategori atau posisi sekolah yang menjadi tempat siswa belajar, seperti perdesaan atau perkotaan, kemudian dilahat juga dari pemilihan gender dan kelas sosial. Kedua metode analisis data secara kualitatif ini dapat digunakan secara serempak dan saling mendukung satu sama lain dalam pencapaian penelitian.

Patut ditambahakan bahwa sebelum melakukan analisis data dengan menggunakan metode padan di atas. Maka langkah-langkah awal yang harus dilakukan adalah: menentukan varibel yang akan diukur menyangkut bangunan subtansi teks, seperti: variabel jenis teks, struktur berpikir teks, pemanfaatan piranti kebahasaan untuk menghubungkan unsur-unsur kebahasaan dalam satu kalimat, pemanfaatan piranti kebahasaan untuk menghubungkan satu kalimatdengan kalimat laindalam pembentukaqn paragraf,dan pemanfaatan piranti kebahasaan untuk menghubungkan 
CENDEKIA, Vol. 13 No. 2 Oktober 2019

p-ISSN: 1978-2098; e-ISSN: 2407-8557

Https://soloclcs.org; Email: cendekiaoslo@gmail.com

Center of Language and Cultural Studies, Surakarta, Indonesia

Irwansyah. (2019). Analisis Kemampuan Memproduksi Teks Anekdot dengan Pendekatan Saintifik Siswa Kelas X MAN 1 Bima: Kajian Teks dalam Pembelajaran Bahasa Indonesia Prof. Mahsun, M.Pd. Cendekia (2019), 13(2): 87-98. DOI: 10.30957/cendekia.v13i2.598..

paragraf satu dengan paragraf laindalam membentuk teks yang memiliki kohesi dan koherensi.

Lebih lanjut, agar data penelitian dapat menampilkan kondisi keseluruhan kemampuan siswa, tahapan analisis lanjutan dari metode padan tehnik HBS,HBB dan HBSP, yaitu menyajikan deskripsi data capaian keseluruhan siswa dalam satu format tabulasi deskripsi akumulasi dan membandingkan hasil deskripsi capaian antara siswa tersebut, agar dapat menggambarkan kemampuan siswa menggunakan piranti kebahasaan teks, dalam menulis teks anekdot melalui pendekatan saintifik.

\section{HASIL DAN PEMBAHASAN}

Berpijak pada sajian hasil data penelitian yakni berupa data kualitatif dan kuantitatif berikut ini dipaparkan pembahasan masing-masing data tesebut.

\subsection{Data Kualitatif}

Melihat sajian data secara kualitatif dengan menggunakan metode padan intaralingual teknik HBS, HBB, dan HBSP, berikut ini pemaparan beberapa aspek sebagai pembahasan atas data yang tersedia dalam lembar deskripsi capean belajar per siswa dalam menulis teks anekdot.

a. Mengamati kemunculan struktur berpikir atau struktur teks tanpaknya siswa kelas X MAN 1 Bima pada kelas IPA 1 dan IPA 2 hampir seluruhnya memiliki kemampuan mengenal dan menerapkan struktur teks anekdot yang meliputi abstaraksi, orientasi, krisis, reaksi, dan koda. terbukti dari teks anekdot yang diproduksi oleh responden, terbukti siswa mampu memunculkan struktur teks yang sesuai dengan struktur teks anekdot.

b. Terkait dengan pemanfatan piranti kebahasaan teks, keterampilan pengungkapan pikiran siswa kelas X MAN 1 Bima pada kelas IPA 1 dan IPA 2 belum seluruhnya mampu menggunakan piranti-piranti kebahasaan sesuai dengan struktur teks anekdot. mengingat kurangnya daya ungkap siswa.

c. Kemampuan daya ungkap tersebut tampak melalui penguasaan dalam penggunaan kosakata yang masih terbatas dari masing-masing siswa, seperti penguasaan kosa kata antonimi, hiponimi, anafora dan penggunaan konjungsi antara kalimat, kemudian juga dapat dilihat dari kemampuan siswa dalam menggunakan kata antonimi, hiponimi, anafora dan penggunaan konjungsi, pada penghubung antara paragraf.

d. Pengembangan kalimat. keterampilan siswa menggunakan piranti penghubung intrakalimat pada konjungsi kesetaraan lebih baik dan lebih sering mendapatkan kemunculan dibandingkan dengan kemunculan konjungsi keberitingkatan yang telah dibuktikan dari lembar deskripsi capaian belajar siswa.

e. Adapun pengembangan paragraf, yang menhubungkan antara kalimat 1 dengan kalimat lain dan paragraf 1 dengan paragraf lainya, siswa sering menggunakan repetisi bentukdibandingkan denga repetisi makna. Hal ini dibuktikan dengan tingginya pemakaian repetisi bentuk antara kalimat dan antara paragraf. 
CENDEKIA, Vol. 13 No. 2 Oktober 2019

p-ISSN: 1978-2098; e-ISSN: 2407-8557

Https://soloclcs.org; Email: cendekiaoslo@gmail.com

Center of Language and Cultural Studies, Surakarta, Indonesia

Irwansyah. (2019). Analisis Kemampuan Memproduksi Teks Anekdot dengan Pendekatan Saintifik Siswa Kelas X MAN 1 Bima: Kajian Teks dalam Pembelajaran Bahasa Indonesia Prof. Mahsun, M.Pd. Cendekia (2019), 13(2): 87-98. DOI: 10.30957/cendekia.v13i2.598..

f. Penggunaan bentuk pengcuan makna yang berfungsi untuk membangun keterhubungan yakni anafora, responden atau siswa lebih sering menggunakan anafora antar kalimat dari pada antar paragraf. Hal ini menyebabkan makna teks anekdot yang dibut siswa atau respoden cukup minim keterkaitan atau keterhubungan.

g. Data di atas juga menggambarkan minimnya keterampilan siswa dalam memanfaatkan diksi bermakna belawanan (antonimi). Gambaran tersebut dibuktikan oleh rendahnya intensitas penggunaan kosakata berantonimi sebagai piranti penghubung antarkalimat dan hanya ditemukan masing-masing satu kali kemunculan dari 10 siswa yang membuat teks.

h. Keterampilan responden dalam penggunaan bentuk yang bermanfaat untuk mengungkapakan sesuatu yang umum dan cakupan-cakupannya tampak sangat minim terbukti kemuculanya hanya pada satu responden yang menggunakan bentuk hiponimi antara kalimat.

i. Selanjutnya konjungsi penghubung antara kalimat, tanpaknya responden cukup terampil menggunakan konjungsi tersebut, walaupun masih ada beberapa responden belum mampu memanfaatkan secara baik. Di samping itu tidak ditemukan adanya penggunaan konjungsi penghubung antar paragraf, untuk mebentuk teks anekdot yang kohesi dan koheren. Dalam pada itu.

Informasi yang terdapat pada lembar deskripsi capaian belajar per siswa tersebut telah meberikan gambaran mengenai keterampilan siswa dalam memanfaatkan piranti kebahasaan dalam menulis teks anekdot. Namun demikian dalam proses pemanfaatan piranti-piranti kebahasaan siswa masih ada sabagian yang belum memanfaatkan pirantipiranti tersebut seperti pada penggunaan piranti penghubung antar kalimat dan penggunaan piranti penghubung antara.

\subsection{Data Kuantitatif Teks Anekdot}

Berdasarkan pengolahan data pada lembar tabulasi, berikut ini sajian pembahasan atas analisis data tersebut secara kuantitatif.

a. Mencermati kelengkapan struktur berpikir atau struktur teks anekdot yang ditulis oleh siswa atau responden, didapati persentase perolehan siswa sebesar $100 \%$. persentase tersebut tergambar melalui intesitas kemunculan dan jumlah respondon yang menerapkan struktur teks pada teks anekdot yang ditulis. Perolehan ini menandakan bahwa jenjang keterampilan siswa kelas X MAN 1 Bima berada pada kategori sangat baik, khususnya dalam menerapkan struktur teks anekdot, meliputi abstraksi, orientasi, krisi, reaksi, dan koda.

b. Hasil perhitungan matematis keterampilan menulis teks anekdot siswa kelas $\mathrm{X}$ MAN 1 Bima (kelengkapan struktur dan penggunaan piranti kebahasaan teks) berada pada kategori kurang terampil, dengan skor perolehan 24 yakni berada dibawa batas skor minimal kategori cukup.

c. Jika dicermati dari segi variabel/kategori kelas, tampak siswa kelas X IPA 1 
memperoleh skor 30 dan siswa kelas X IPA 2 memperoleh skor 30. Skor perolehan kedua kelas sampel penelitian ini tidak menunjukan perbedaan jenjang keterampilan dalam menulis teks anekdot melalui pendekatan saintifik, keduanya berada pada kategori kurang terampil.

d. Gambaran kuantitatif keterampilan sampel penelitian menulis teks anekdot melalui pendekatan saintifik, sebagaimana pemaparan point sebelumnya menyiratkan bahwa tidak terdapat perbedaan perihal capaian belajar siswa, baik siswa kelas X IPA 1 maupun kelas X IPA 2.

e. Secara kuantitatif, data penelitian menunjukan siswa kelas X IPA 1 dan kelas $X$ IPA 2 memiliki tingkat keterampilan yang sama dalam menulis teks anekdot. Hal ini dibuktikan dari jumlah skor yang didapat oleh kedua kelas tersebut, yaitu kelas X IPA 1 mendapat skor 30 dan X IPA 2 mendapat skor 30. dari skor tersebut kemampuan ke dua kelas tersebut dapat dikatakan kurang terampil dalam menulis teks anekdot menggunakan metode saintifik.

Mengulas data di atas, tampaknya perolehan skor dan penetapan tingkat keterampilan siswa $\mathrm{X}$ MAN 1 Bima dalam menulis teks anekdot menggunakan pendekatan saintifik berada pada nilai kurang terampil. hal ini dipengaruhi oleh kurang siswa dalam membiasakan diri dalam menulis sebuah teks atau cerita. kemudian dari pada itu kemampuan tersebut kurang terampilnya guru dalam menyajikan sebuah meteri pembelajaran atau desain pembelajaran.

Kemudian dilihat daridata tabel penilaian menggambarkan bahwa kemampuan siswa kelas X MAN 1 Bima dalam menulis teks anekdot menggunakan metode saintifik berada pada nilai kurang terampil, Hal ini dibuktikan dari nilai siswa hanya berada pada rentang dibawah skor minimal. hal tersebut juga dibuktikan dari hasil analisis data kualitatif dan analisis data kuantitatif dengan menggunakan lembar tabulasi data yang menunjukan angka kemampuan menulis teks anekdot siswa keseluruhan mendapat skor 30 yaitu berada pada kategori nilai kurang terampil.

\section{SIMPULAN}

Berdasarkan data di atas, maka dapat disimpulkan bahwa tampaknya perolehan skor dan penetapan tingkat keterampilan siswa X MAN 1 Bima dalam menulis teks anekdot menggunakan pendekatan saintifik berada pada nilai kurang terampil. hal ini dipengaruhi oleh kurang siswa dalam membiasakan diri dalam menulis sebuah teks atau cerita. kemudian dari pada itu kemampuan tersebut kurang terampilnya guru dalam menyajikan sebuah materi pembelajaran atau desain.

\section{DAFTAR PUSTAKA}

Arikunto, Suharsimi. 2010. Prosedur Penelitian Suatu Pendekatan Praktis. Jakarta: PT. Rineka Cipta.

Dewi Rahmayanti, Inengah Martha, Ni Md, Rai Wisudariani. 2015. Pembelajaran Menulis Teks Anekdot Pada Mata Pelajaran Bahasa Indonesia dalam Kurikulum 2013 di Kelas X.A Akuntasi SMK Negeri 1 Singaraja. Dalam E- 
Jurnal JPBSI Universitas Pendidikan Ganesha Volume 3 No.1 Tahun 2015. Universitas Pendidikan Ganesha.

Gottschalk, Louis. 1986. Understanding History: A Primer of Historical Method (terjemahan Nugroho Notosusanto). Jakarta: UI Press.

Hanafi, Hilaludin. 2014. Pendekatan Saimtifik dalam perspektif Pembelajaran Bahasa dan Sastra Indonesia: Kasus pada Materi Menulis Puisi dan Menulis Teks", Proseding Simposium Imternasional: Bahasa, Sastra dan Budaya Indonesia dalam Pengembangan Profenasionalisme edidi Oktober 2014. Makassar: Universitas Negeri Makasar.

Kemendikbud. 2013. Buku Guru: Bahasa Indonesia Ekspresi Diri dan Akademik untuk Kelas X. Jakarta: Kementerian Pendidikan dan Kebudayaan.

Mahsun. 2014a. Teks Dalam Pembelajaran Bahasa Indonesia Kurikulum 2013. Jakarta: PT RajaGrafindo Persada

Mahsun. 2014b. Teks Pembelajaran Bahasa Indonesia Kurikulum 2013. Jakarta: PT RajaGrafindo Persada

Mahsun. 2017. Metode Penelitian Bahasa Tahapan Strategis. Metode, dan Tekniknya Edisi Revisi Ketiga. Jakarta: Rajawali Pers.

Maria Made Iis Hermawati, Nyomang Sudiana, dan I Gede Nurjaya. 2015. Implementasi Pendekatan Saintifik Pada Kurikulum 2013 dalam Pembelajaran Menulis di kelas X IIS 1 SMAN 1 Mendoyo, dlam E-Jurnal Universitas Pendidikan Ganesa Volume 3 No. 1 Tahun 2015.Singaraja

Moleong, Lexy J. 2013. Metode Penelitiaan Kualitatif Edisi Revisi. Bandung: Remaja Rosda Karya.

Pardiyono. 2017, teaching genre based writing. Yogyakarta: andi

Sudarsana, I Kadek, I Wayang Rasna, dan I Wayang Artika. 2015. Penerapan Model Pembelajaran Berbasis Proyek (project based learning) dalam Pembelajaran Menulis Teks Prosedur Kompleks Oleh Guru di Kelas XBahasa dan Budaya di SMA Negeri 4 Singaraja" dalam E-Jurnal Program Pascasarjana Universitas Pendidikan Ganesha Volume 3 Nomor 1 Tahun 2015. Singaraja: Program Studi Pendidikan Bahasa, Program Pascasarjana Universitas Pendidikan Ganesha.

Sugiyono. 2016. Metode Penelitian Pendidikan Pendekatan Kualitatif, Kuantitaf dan $R \& D$. Bandung. Alfabeta.

Sugiyono. 2014. Metode Penelitian Kuantitatif, Kualitatif, dan R\&D. Bandung. Alfabeta.

Syukur Ibrahim. Abdul. 2007. Metode Analisis Teks \& Wacana, Yokyakarta: Pustaka Pelajar.

Sutopo, HB. 2006, Metode Penelitian Kualitatif, Surakarta: UNS Press.

Wyn Somodana, I.B Sutresna, Md Sri Indriani. 2015. Penerapan Model Pemebelajaran Berbasis Masalah (Problem Based Learning) Dalam Pemebelajaran Menulis Teks Anekdot. Dalam E-Jurnal Universitas Pendidikan Ganesha. Volume 3 No. 1 Tahun 2015. Universitas Pendidikan Ganesha. 